\title{
New early Pliocene owls from Langebaanweg, South Africa, with first evidence of Athene south of the Sahara and a new species of Tyto
}

\author{
Marco Pavia, Albrecht Manegold, and Pippa Haarhoff \\ Acta Palaeontologica Polonica 60 (4), 2015: 815-828 doi:http://dx.doi.org/10.4202/app.00077.2014
}

The fossiliferous Upper Varswater Formation at Langebaanweg (South Africa) produced remains of at least five species of owls (Strigiformes). Tyto richae sp. nov. is the first palaeospecies of Tytonidae described from an African fossil site, though indeterminate remains referable to the genus Tyto are known from the Middle Miocene of Morocco, the early Pliocene of Ethiopia, and the Pliocene of Tanzania. Athene inexpectata sp. nov. is not only the earliest documented fossil evidence for the genus worldwide, but also the first record of a species of Athene in Africa south of the Sahara. Proportions of its hind limb indicate that At. inexpectata sp. nov. probably has been as terrestrial as its modern relative At. cunicularia. A few additional remains represent the earliest fossil evidence for the genera Asio and Bubo on the African continent, though the poor preservation of these bones prevents more detailed identifications. A distal tibiotarsus of a small owl about the size of At. inexpectata sp. nov. indicates the presence of a fifth, as yet indeterminate, species of owl at Langebaanweg. Biogeographical and palaeoecological implications of this assemblage of owls are discussed.

Key words: Aves, Strigiformes, Tytonidae, Strigidae, Varswater Formation, Pliocene, Africa, Langebaanweg.

Marco Pavia [marco.pavia@unito.it], Museo di Geologia e Paleontologia, Dipartimento di Scienze della Terra, Università degli Studi di Torino, Via Valperga Caluso 35, I-10125 Torino, Italy; Albrecht Manegold [albrecht.manegold@ smnk.de ], Senckenberg Forschungsinstitut und Naturmuseum, Senckenberganlage 25, D-60325 Frankfurt/Main, Germany; present address: Staatliches Museum für Naturkunde Karlsruhe, Erbprinzenstr. 13, D-76133 Karlsruhe, Germany; Pippa Haarhoff [pjh@fossilpark.org.za], West Coast Fossil Park, PO Box 42, Langebaanweg, ZA-7375, South Africa. 
This is an open-access article distributed under the terms of the Creative Commons

Attribution License (for details please see creativecommons.org), which permits unrestricted use, distribution, and reproduction in any medium, provided the original author and source are credited.

FoF 